\title{
PENGARUH KUALITAS LAPORAN KEUANGAN DAN DEBT MATURITY TERHADAP EFISIENSI INVESTASI PERUSAHAAN MANUFAKTUR SEKTOR KONSUMSI YANG TERDAFTAR DI BURSA EFEK INDONESIA
}

\author{
Gina Septiana ${ }^{1)}$ Luci Yanul Ikhsan ${ }^{2)}$ \\ ${ }^{1) 2)}$ Prodi Akuntansi, SekolahTinggi Ilmu Ekonomi KBP Padang \\ ${ }^{1)}$ Email: ginaseptiana0988@gmail.com \\ ${ }^{2)}$ Email: luciyanulikhsan14@gmail.com \\ Submited: 2019.10.24 Reviewed: 2019.11.05 Accepted: 2019.11.19 \\ https://doi.org/10.34006/jmbi.v8i2.121
}

\begin{abstract}
This study aims to examine the effect of the quality of financial statements and debt maturity on investment efficiency of consumption sector manufacturing company which listed in Indonesia Stock Exchange from 2015 to 2017. The method of data collection is done by documenting data sourced from annual reports published through the Indonesia Stock Exchange. The sample in this study were 21 companies listed on the Indonesian stock exchange that were selected using purposive sampling. The analytical method used is the panel regression model. Data were tested using Eviews software version 8.0. based on hypothesis testing results show that the quality of financial statements has a positive and significant effect on investment efficiency while debt maturity has no significant effect on investment efficiency.
\end{abstract}

Keywords : Quality of Financial Statements, Debt Maturity, Investment Efficiency

Abstrak

Penelitian ini bertujuan untuk menguji pengaruh kualitas laporan keuangan dan debt maturity terhadap efisiensi investasi. Perusahaan Manufaktur Sektor Konsumsi di Bursa Efek Indonesia 2015-2017. Metode pengumpulan data dilakukan dengan dokumentasi data yang bersumber dari laporan tahunan yang dipublikasikan melalui Bursa Efek Indonesia. Sampel dalam penelitian ini adalah 21 perusahaan yang terdaftar di bursa efek indonesia yang dipilih menggunakan purposive sampling. Metode analisis yang digunakan adalah model regresi panel. Data diuji menggunakan perangkat lunak Eviews versi 8.0. berdasarkan hipotesis hasil pengujian menunjukan bahwa kualitas laporan keuangan berpengaruh positif dan signifikan terhadap efisiensi investasi sedangkan debt maturity tidak berpengaruh sigifikan terhadap efisiensi investasi.

Kata Kunci : Kualitas Laporan Keuangan, Debt Maturity, Efisiensi Investasi

\section{PENDAHULUAN}

Keadaan bisnis di Indonesia saat ini bertambah maju. Hal ini dapat dibuktikan dari indeks tendensi bisnis tahunan Badan Pusat Statistik. Dalam meningkatkan keadaan suatu bisnis diperlukan beberapa faktor-faktor pendukung salah satunya ialah peningkatan kapasitas produksi atau usaha. Dengan melakukan investasi, kapasitas produksi atau usaha perusahaan dapat ditingkatkan dengan cara berinvestasi tersebut. Secara lazim investasi dapat didefinisikan sebagai keputusan mengeluarkan beberapa sejumlah dana pada saat sekarang guna membeli aset riil (tanah, rumah, mobil, dan sebagainya) atau aset keuangan (saham, obligasi, reksadana, wesel, dan sebagainya) yang bertujuan untuk mendapatkan keuntungan yang lebih besar di masa yang mendatang (Basalamah dan Haming, 2010).

Dalam berinvestasi, suatu perusahaan sangat diharuskan melakukan investasi yang efisien agar investasi itu dapat berguna lebih baik untuk sebuah perusahaan. Perusahaan diharapkan mampu merencanakan dan memanfaatkan sumber daya secara tepat agar dapat mencapai investasi yang optimum dan dapat terhindar dari keadaan overinvestment dan underinvestment. Overinvestment adalah suatu keadaan di mana investasi yang dilakukan 
perusahaan lebih tinggi dari pada yang diharapkan. Berkebalikan dengan overinvestment, underinvestment adalah suatu keadaan di mana investasi yang dilakukan perusahaan lebih rendah dari pada yang diharapkan (Sakti, 2015).

Keputusan-keputusan yang diambil oleh manajer suatu perusahaan sangat berpengaruh penting terhadap pertumbuhaan perusahaan tersebut. Suatu perusahaan sangat membutuhkan informasi-informasi pasti dan benar yang berguna bagi perusahaan dan manajer dituntut untuk mengetahui informasi-informasi tersebut. Tetapi, di beberapa perusahaan juga ada manajer perusahaannya yang menyalahgunakan informasi-informasi yang diketahui untuk kepentingan dirinya sendiri. Manajer tersebut menyampaikan keadaan perusahaan yang tidak sama dengan kondisi perusahaan yang sesungguhnya. Keadaan tersebut dikarenakan antara manajer dan pemegang saham memiliki informasi yang berbeda. Dibandingkan dengan pemegang saham, seorang manajer lebih mengetahui informasiinformaasi yang ada pada perusahaan karna serang manajer juga bertugas sebagai pengelola perusahan. Kondisi yang seperti ini dapat dikatakan dengan asimetri informasi yaitu suatu kondisi di mana seorang manajer mempunyai akses informasi terhadap prospek perusahaan yang tidak dimiliki oleh pihak luar purusahaan (stakeholder/pemegang saham).

Investasi merupakan komitmen memuat beberapa sejumlah dana pada saat sekarang yang bertujuan untuk mencapai laba yang besar di masa yang akan datang. Sedangkan keputusan investasi merupakan suatu aktivitas yang dilkerjakan oleh seorang individu untuk menentukan suatu pilihan dari dua atau lebih alternatif sesudah dilakukan berbagai macam proses identifikasi sehingga terbentuknya kesimpulan yaitu keputusan untuk berinvestasi (Sulistyowati, 2015).

Kualitas laporan keuangan dan debt maturity dalam hal ini dijadikan sebagai dasar pertimbangan oleh investor dalam menentukan keputusan investasi yang tepat, sehingga investasi yang dilakukan akan menjadi efisien. Dalam berinvestasi, perusahaan juga dituntut untuk berinvestasi secara efisien supaya investasi tersebut bermanfaat yang baik bagi perusahaan. Penggunaan asset maupun penanaman modal perusahaan secara tepat agar tidak terjadi pemborosan sumber daya yang ada dengan menekan biaya perusahaan dan mengelola perusahaan secara optimal, untuk mencapai tujuan perusahaan yang menguntungkan. Agar investasi menjadi efisien, maka perusahaan harus terhindar dari masalah overinvestment maupun masalah underinvestment disebut dengan efisiensi investasi. (Christine \& Yanti, 2017)

\section{TINJAUAN PUSTAKA DAN HIPOTESIS}

\section{Efisiensi Investasi}

Efisiensi yaitu suatu tindakan yang memanfaatkan sumber daya dengan tepat dan benar, tidak terjadinya pemborosan sumber daya yang ada. Sebuah perusahaan biasanya melakukan efisiensi untuk menekan biaya dan memudahkan proses pengelolaan perusahaan supaya dapat dengan mudah mencapai suatu tujuan perusahaan. Kegiatan investasi yang dilakukan perusahaan haruslah efisien supaya dapat menguntungkan dan dapat bermanfaat bagi suatu perusahaan. Efisiensi investasi adalah tingkat investasi yang optimal dari suatu perusahaan, yang mana investasi tersebut merupakan bentuk investasi yang dapat menguntungkan bagi sebuah perusahaan. Agar suatu investasi dapat dikatakan efisien, perusahaan seharusnya dapat terhindar dari masalah overinvestment dan underinvestment (Sari, 2014).

\section{Kulitas Laporan Keuangan}

(Ulum Tri Handayani, 2016) menjelaskan bahwa kualitas pelaporan yang tinggi maka akan dapat mengurangi asimetri informasi sehingga dapat meningkatkan efisiensi investasi dalam sebuah perusahaan. Sementara itu, analyst following juga berperan penting sebagai pihak yang melakukan monitoring di luar perusahaan dan juga mampu menurunkan asimetri 
informasi serta dapat membantu investor dalam pengambilan keputusan investasi. Dengan adanya analyst following, pentingnya kualitas pelaporan keuangan akan meningkat karena analyst following adalah salah satu pemakai laporan keuangan (investor, karyawan, kreditur, pemasok, pemerintah, pelanggan, masyarakat) untuk kemudian dianalisis agar dapat menghasilkan penilaian dan proyeksi seperti perkiraan keuntungan per lembar saham di masa yang akan datang untuk suatu perusahaan. Dengan yang demikian, analyst following akan dapat mendorong sebuah perusahaan supaya lebih transparan dalam mengungkapkan informasi-informasi terutama yang telah disajikan dalam laporan keuangan.

\section{Debt maturity}

Maturitas adalah jangka waktu jatuh tempo, jadi maturitas utang (debt maturity) merupakan jangka waktu jatuh tempo utang yang akan digunakan oleh sebuah perusahaan. Jatuh tempo utang dibagi menjadi dua bagian, yaitu utang jangka pendek dan utang jangka panjang Rahmawati (2016). Utang jangka pendek merupakan utang uang memiliki jatuh tempo kurang dari satu tahun serta bagian dari utang jangka panjang yang akan jatuh tempo pada tahun berjalan. Jatuh tempo suatu utang akan menyebabkan adanya arus kas keluar dan akan menjadi salah satu pertimbangan perusahaan dalam mengalokasikan investasi pada tahun berjalan (Amrullah, 2013). Debt Maturity merupakan salah satu aspek utama bagi perusahaan di dalam memutuskan untuk melakukan pendanaan, yang mana dapat digunakan sebagai penyedia informasi mengenai kualitas, kredibilitas, dan prospek ke depan dari sebuah perusahaan (Putradiantara, 2017).

\section{Pengembangan Hipotesis}

Sesuai dengan penelitian terdahulu yang berhubungan dengan penelitian ini juga pernah dilakukan oleh (Amrullah, 2013), (Rahmawati \& Harto, 2014), (Sakti, 2015), (Christine \& Yanti, 2017) menemukan bahwa kualitas laporan keuangan berpengaruh positif terhadap efisiensi investasi. Berbeda dengan penelitian sebelumnya, penelitian (Sari, 2014) yang menemukan bahwa kualitas laporan keuangan berpengaruh negatif terhadap efisiensi investasi. Menurut teori dan hasil penelitian, semakin tinggi kualitas laporan keuangan akan meningkatkan efisiensi investasi hal ini dikarenakan kualitas laporan keuangan secara langsung mempengaruhi para manajer menjadi lebih akuntabel, sehingga dapat mengurangi asimetri informasi dan menurunkan tingkat moral hazard dalam menentukan keputusan investasi.

Berdasarkan teori dan hasil penelitian maka peneliti mengajukan hipotesis yang akan dibuktikan secara empiris:

\section{$\mathrm{H}_{1}$ : Kualitas Laporan Keuangan berpengaruh positif terhadap Efisiensi Investasi}

Berdasarkan penelitian terdahulu yang dilakukan oleh (Amrullah, 2013), (Sakti, 2015), (Christine \& Yanti, 2017) menemukan bahwa debt maturity berpengaruh positif terhadap efisiensi investasi. Dalam kasus overinvestment, debt maturity yang rendah dapat menurunkan tingkat investasi perusahaan karena adanya kewajiban mengembalikan pinjaman. Sedangkan dalam kasus underinvestment, debt maturity dapat meningkatkan tingkat efisiensi investasi dengan menjadi sumber pendanaan manajer untuk melakukan investasi pada proyek NPV positif.

Penelitian tersebut bertolak belakang dengan penelitian yang dilakukan oleh (Rahmawati \& Harto, 2014) menemukan bahwa debt maturity tidak berpengaruh terhadap efisiensi investasi.

Berdasarkan teori dan hasil penelitian maka peneliti mengajukan hipotesis yang akan dibuktikan secara empiris:

\section{$\mathrm{H}_{2}$ : Debt Maturity berpengaruh positif terhadap Efisiensi Investasi}




\section{METODE PENELITIAN}

\section{Populasi dan Sampel}

Populasi pada penelitian ini adalah seluruh perusahaan manufaktur sektor konsumsi yang terdaftar di Bursa Efek Indonesia tahun 2015-2017. Teknik pengambilan sampel yang digunakan adalah teknik sampling secara non-probabilitas, dengan teknik pengambilan sampel yaitu Purposive Sampling yang didasarkan dari pemilihan kriteria-kriteria yang mempunyai keterkaitan dengan karakteristik yang telah diketahui sebelumnya, yaitu 1) Perusahaan manufaktur yang terdaftar di Bursa Efek Indonesia sektor konsumsi. 2) Perusahaan yang menerbitkan laporan keuangan tahunan selama periode penelitian dari tahun 2015-2017. 3) Perusahaan yang tidak delisting pada periode penelitian tahun 2015-2017. Delisting adalah penghapusan pencatatan yang terjadi apabila saham yang tercatat di Bursa mengalami penurunan kriteria sehingga tidak memenuhi persyaratan pencatatan, maka saham tersebut dikeluarkan dari pencatatan di Bursa. 4) Perusahan yang mempunyai laba positif selama periode penelitian tahun 2015-2017.

Populasi sebanyak 53 perusahaan manufaktur sektor konsumsi tahun 2015-2017, sebanyak 21 perusahaan dipilih karena lolos dalam pemilihan kriteria. Berikut adalah gambaran pemilihan sampel perusahaan:

Tabel 1

Kriteria Purposive Sampling Method

No

1 Jumlah perusahaan manufaktur sektor konsumsi di BEI

2 Perusahaan yang menerbitkan annual report selama periode penelitian dari tahun 2015-2017

3 Perusahaan yang tidak delisting pada periode observasi

4 Perusahan yang mempunyai laba positif selama periode penelitian tahun 2015-2017

Jumlah sampel

Jumlah observasi $21 \times 3$
Jumlah

53

63

\section{Definisi operasional variabel}

Variabel dependent pada penelitian ini adalah efisiensi invetasi, sedangkan variabel independentnya yaitu kualitas laporan keuangan dan debt maturity

Tabel 2

\section{Operasionalisasi Variabel Penelitian}

\begin{tabular}{|l|l|l|}
\hline $\begin{array}{c}\text { Nama } \\
\text { Variabel }\end{array}$ & \multicolumn{1}{|c|}{ Definisi } & \multicolumn{1}{|c|}{ Pengukuran } \\
\hline Efisiensi & penggunaan asset maupun penanaman modal & Investmenti, $\mathrm{t}=\beta 0+$ \\
Investasi & $\begin{array}{l}\text { perusahaan secara tepat agar tidak terjadi } \\
\text { pemborosan sumber daya yang ada dengan }\end{array}$ & $\beta 1^{*}$ Sales Growthi,t-1 + \\
& $\begin{array}{l}\text { menekan biaya perusahaan dan mengelola } \\
\text { perusahaan secara optimal untuk mencapai }\end{array}$ & \\
\hline
\end{tabular}




\begin{tabular}{|c|c|c|}
\hline Nama & Definisi & Pengukuran \\
\hline & $\begin{array}{l}\text { tujuan perusahaan yang menguntungkan } \\
\text { disebut dengan efisiensi investasi. (Christine \& } \\
\text { Yanti, 2017) }\end{array}$ & \\
\hline $\begin{array}{l}\text { Kualitas } \\
\text { Laporan } \\
\text { Keuangan }\end{array}$ & $\begin{array}{l}\text { Laporan keuangan yang di dalamnya memuat } \\
\text { informasi yang tepat mengenai operasional } \\
\text { perusahaan, khususnya arus kas yang } \\
\text { diharapkan, yang menjadi sumber bagi investor } \\
\text { (Umiyati, 2017) }\end{array}$ & $\begin{array}{c}\text { WCAi, } t=\beta 0+ \\
\beta 1 C F O i, t-1+ \\
\beta 3 C F O i, t+\beta 3 C F O i, t+1 \\
+\varepsilon \mathrm{i}, \mathrm{t}\end{array}$ \\
\hline $\begin{array}{l}\text { Debt } \\
\text { Maturity }\end{array}$ & $\begin{array}{l}\text { Sebuah kebijakan yang dilakukan oleh } \\
\text { perusahaan dalam menentukan jatuh tempo } \\
\text { utang yang akan digunakan perusahaan } \\
\text { (Rahmawati \& Harto, 2014) }\end{array}$ & $S T D e b t=\frac{\text { Utang Jgk Pendek }}{\text { Total Hutang }}$ \\
\hline
\end{tabular}

\section{Teknik analisis data}

Pembuktian mengenai kebenaran hipotesis maka digunakan metode analisis dengan cara kuantitatif, dilakukan menggunakan pembentukan metode pengujian kelayakan Model Effect Regresi Panel yaitu Regresi Fixed Effect Model Dan Random Effect Model.

Menurut (Winarno, 2009) mengungkapkan secara umum model panel regresi yang digunakan mengetahui arah dan besarnya pengaruh variabel independen terhadap variabel dependen secara individual. Model regresi yang akan dibentuk dan dianalisis maka terlebih dahulu dilakukan pengujian kelayakan pada model regresi panel dengan menggunakan uji sebagai berikut:

\section{Pengujian Likelihood Ratio}

Tahapan memulai pengujian regresi panel dengan mengukur pembentukan regresi fixed effect model maka terlebih dalam melakukan pengujian uji likelihood, untuk mendeteksi masalah adanya variabel yang tidak penting di dalam model bisa dilakukan dengan uji Likelihood Ratio (LR). Misalnya kita mempunyai model regresi sebagai berikut: (Winarno, 2009)

$$
\mathrm{Y}=\beta 0+\beta 1 \mathrm{X} 1+\beta 2 \mathrm{X} 2+\beta 3 \mathrm{X} 3+\mu
$$

Didalam pengujian likelihood ratio sebuah model regresi dapat diterima ketika nilai probability dari F-statistik di bawah 0,05, atau seluruh variabel independen yang mendukung model regresi panel memiliki probability di bawah 0,05 . Sehingga kesimpulannya adalah Ho ditolak dan Ha diterima atau pemilihan regresi panel dengan Fixed Effect Model (FEM) lebih baik untuk digunakan dibandingkan dengan model regresi panel yang lain. Begitupun sebaliknya, pengujian likelihood ratio tidak dapat diterima ketika nilai probability dari Fstatistik di atas 0,05. Sehingga kesimpulannya adalah Ho diterima dan Ha ditolak atau pemilihan regresi panel dengan Fixed Effect Model (FEM) tidak baik untuk digunakan dibandingkan dengan model regresi panel yang lain. 


\section{Pengujian Hausman Test}

Tahapan memulai pengujian regresi panel dengan mengukur pembentukan regresi random effect model maka terlebih dalam melakukan pengujian uji hausman test. Pengujian Hausman test telah mengembangkan uji secara umum ke salah satu spesifikasi yang dikenal dengan uji kesalahan spesifikasi regresi (Regression Spesification Error Test=RESET), (Winarno, 2009). Secara umum model pengujian Hausman test bisa dijelaskan dengan model sebagai berikut:

$$
\mathrm{Yit}=\beta 0+\beta 1 \mathrm{X} 1+\beta 2 \mathrm{X} 2+\beta 3 \mathrm{X} 3+\mathrm{Uit}
$$

Di dalam pengujian Hausman Test, Random Effect Model (REM) dapat diterima bila nilai $F$-prob yang dihasilkan didalam pengujian berada diatas 0,05 atau nilai F-hit $<$ F-tabel. Sehingga kesimpulannya adalah Ho di tolak dan Ha diterima atau pemilihan regresi panel dengan Random Effect Model (REM) lebih baik untuk digunakan dibandingkan dengan model regresi panel yang lain. Begitupun sebaliknya, pengujian Hausman Test, Random Effect Model (REM) tidak dapat diterima bila nilai $F$-probability yang dihasilkan didalam pengujian berada dibawah 0,05 atau nilai F-hit < F-tabel. Sehingga kesimpulannya adalah Ho diterima dan Ha ditolak atau pemilihan regresi panel dengan Random Effect Model (REM) tidak baik untuk digunakan dibandingkan dengan model regresi panel yang lain (Winarno, 2009).

Pengolahan data dalam penelitian dilakukan dengan menggunakan Eviews 8 dan melakukan analisis menggunakan model regresi panel. Pada penelitian ini model regresi panel yang digunakan dalam bentuk berganda yang dapat dirumuskan kedalam penelitian ini adalah:

$$
\text { Yit }=\beta 0+\beta 1 \mathrm{Xit}+\beta 2 \mathrm{X} 2 \mathrm{it}+\beta 3 \mathrm{X} 3 \mathrm{it}+\mathrm{e}
$$

Berdasarkan model regresi panel dapat di jelaskan bahwa Yit merupakan Jumlah Efisiensi Investasi, Xit merupakan Kualitas Laporan Keuangan tahun tertentu, X2it merupakan Debt Maturity pada tahun tertentu dan $\beta 0$ merupakan konstanta bila $\mathrm{X}=0$

\section{Pengujian Hipotesis}

Pengujian hipotesis yang dilakukan menggunakan menggunakan pengujian $t$ statistik dan pengujian koefisien determinasi ( $R$-Square) yaitu dengan menggunakan program Eviews 8. Koefisien determinasi ( $R$-Square) menjelaskan tentang seberapa kemampuan model dalam merangkan variabel independen (variabel bebas) berpengaruh terhadap variabel independen (variabel terikat). Koefisien variabel dependen dalam penelitian adalah kualitas laporan keuangan dan debt maturity sedangkan variabel dependen adalah efisiensi investasi. Nilai yang dimiliki Adjusted $R$ Square yaitu antara angka 0 sampai 1. Nilai Adjusted $R$ Square dikatakan semakin besar apabila mendekati angka satu yang memperlihatkan bahwa model yang dirumuskan tersebut telah menjelaskan perubahan efisiensi investasi (Mansuri, 2016).

Pengujian $\mathrm{t}$ statistik merupakan suatu uji statistik yang digunakan untuk melihat sejauh mana pengaruh variabel independen terhadap variabel secara parsial atau individu dimana kriteria didalam pengambilan keputusannya adalah Kriteria Pengujian adalah 1) Jika probabilitas $\leq$ alpha 0,05 maka keputusannya adalah Ho ditolak dan Ha diterima maka dapat disimpulkan bahwa variabel independen berpengaruh signifikan terhadap variabel dependen secara individual. 2) Jika probabilitas $\geq$ alpha 0,05 maka keputusannya adalah Ho diterima dan Ha ditolak maka dapat disimpulkan bahwa variabel independen tidak berpengaruh signifikan terhadap variabel dependen secara individual (Mansuri, 2016). 


\section{HASIL DAN PEMBAHASAN}

\section{Pengujian Kelayakan Model Regresi Panel}

Pengujian Hausman test

Pengujian prasyarat yang diterima menggunakan model Regresi Random dengan pengujian Hausman Test. Didalam pengujian Hausman Test, Random Effect Model (REM) dapat diterima bila nilai $F$-probability yang dihasilkan didalam pengujian berada diatas 0,05 . Berdasarkan hasil pengujian yang telah dilakukan diperoleh ringkasan hasil terlihat pada tabel 3 di bawah ini:

Tabel 3

\section{Hasil Pengujian Hausman Test}

\begin{tabular}{lrcr}
\hline \hline Test Summary & $\begin{array}{r}\text { Chi-Sq. } \\
\text { Statistic }\end{array}$ & Chi-Sq. d.f. & Prob. \\
\hline \hline Cross-section random & 5.697375 & 2 & 0.0579 \\
\hline \hline
\end{tabular}

Sumber : Hasil Pengolahan Data Eviews 2019

Sesuai dengan hasil pengujian yang telah dilakukan diperoleh nilai prob cross section random sebesar 0,0579, proses pengolahan dilakukan dengan menggunakan tingkat kesalahan sebesar 0,05. Hasil yang diperoleh didalam pengujian Husman Test menunjukan bahwa nilai prob sebesar $0,0579 \geq$ alpha 0,05 maka didalam model penelitian ini dapat disimpulkan penggunaan Random Effect Model (REM) bisa diterima.

\section{Regresi Random Effect Model}

Berdasarkan pengujian dalam pembentukan model maka peneliti mengambil keputusan memilih regresi Random Effect Model (REM). Peneliti melihat model regresi REM memiliki nilai probability dan nilai hubungan pengaruh variabel independen terhadap Efisiensi Investasi lebih tinggi dibandingkan model regresi Fixed Effect Model (FEM), oleh karena itu peneliti memilih menggunakan pembentukan model regresi effect model di dalam model analisis regresi panel di dalam penelitian.

\section{Tabel 5}

\section{Hasil Pengujian Regresi Random Effect Model}

\begin{tabular}{crrrrrr} 
Variable & Coefficient & Std. Error & t-Statistic & Prob. & Alpha & Kesimpulan \\
\hline \hline C & 2.851449 & 4.356545 & 0.654521 & 0.5185 & & \\
LOGKLK & 0.139272 & 0.066258 & 2.101977 & 0.0454 & 0,05 & Signifikan \\
LOGDM & -0.135122 & 0.458183 & -0.294909 & 0.7704 & 0,05 & Tidak signifikan \\
\hline \hline
\end{tabular}

Sumber : Hasil Pengolahan Data Eviews 2019

Sesuai dengan hasil pengujian terlihat masing masing variabel independen telah memiliki koefisien regresi panel yang dapat dibuat kedalam sebuah model regresi panel dengan menggunakan model Random Effect Model (REM) terlihat di bawah ini:

$$
Y_{\text {it }}=2.851449+0.139272 X_{1 i t}+-0.135122 X_{2 i t}
$$


Pada model regresi terlihat nilai konstanta yang dihasilkan adalah sebesar 2.851449 nilai yang diperoleh tersebut mengisyaratkan bahwa jika diasumsikan tidak terjadi terjadi perubahan (peningkatan atau penurunan) variable kualitas laporan keuangan dan debt maturity maka nilai jumlah Efisiensi Investasi adalah sebesar 2.851449 dengan demikian dapat disimpulkan tanpa keberadaan variabel kualitas laporan keuangan dan debt maturity jumlahEfisiensi Investasi pada perusahaan manufaktur sektor konsumsi di Bursa Efek Indonesia masih relatif meningkat.

Di dalam model persamaan regresi panel juga terlihat bahwa variabel kualitas laporan keuangan memiliki nilai koefisien regresi bertanda positif sebesar 0.139272 . Nilai koefisien yang diperoleh menunjukan bahwa ketika diasumsikan terjadi peningkatan nilai kualitas laporan keuangan yang dimiliki perusahaan manufaktur sektor konsumsi di Bursa Efek Indonesia sebesar 1x akan mendorong meningkatnya Efisiensi Investasi sebesar 0.139272x dengan asumsi faktor lain selain variabel kualitas laporan keuangan dianggap tetap atau konstan dan sebaliknya.

Pada model regresi panel yang telah terbentuk juga teridentifikasi bahwa variabel Debt Maturity memiliki koefisien regresi sebesar -0,135122 nilai koefisien yang diperoleh menunjukan bahwa ketika diasumsikan terjadi penurunan, yang artinya dalam setiap penggunaan debt maturity sebesar 1x tidak dapat meningkatkan Efisiensi Investasi pada perusahaan manufaktur sektor konsumsi di Bursa Efek Indonesia sebesar -0,135122x dengan asumsi faktor lain selain variabel debt maturity dianggap konstan atau tetap dan sebaliknya.

Koefisien Determinan (R_Squere)

\section{Tabel 4.8 \\ Hasil Pengujian Koefisien Determinan $\left(R \_S q u e r e\right)$}

\begin{tabular}{lr}
\multicolumn{1}{c}{ Keteragan } & Koefisien \\
R-square & 0.162836 \\
Adjusted R-square & 0.098439
\end{tabular}

Sumber : Hasil Pengolahan Data Eviews 2019

Berdasarkan hasil pengujian koefisien determinasi diperoleh nilai $R$-square sebesar 0.162836 hasil yang diperoleh tersebut mengisyaratkan bahwa variabel kualitas laporan keuangan dan debt maturity memiliki variasi kontribusi dalam mempengaruhi Efisiensi Investasi sebesar $16 \%$ sedangkan sisanya $84 \%$ lagi dijelaskan oleh variabel lain yang belum digunakan didalam penelitian saat ini.

\section{Pengujian Hipotesis Kualitas Laporan Keuangan Terhadap Efisiensi Investasi}

Sesuai dengan hasil pengujian hipotesis pertama dengan menggunakan variabel kualitas laporan keuangan diperoleh nilai probability sebesar 0.0454 , dengan menggunakan tingkat kesalahan 0,05. Hasil yang diperoleh menunjukan bahwa nilai sig sebesar $0.0454 \leq$ alpha 0,05 maka keputusannya adalah Ho ditolak dan Ha diterima sehingga dapat disimpulkan bahwa kualitas laporan keuangan yang diukur dengan modal kerja akrual berpengaruh positif dan signifikan terhadap Efisiensi investasi pada perusahaan manufaktur sektor konsumsi di Bursa Efek Indonesia.

\section{Pengujian Hipotesis Debt Maturity Terhadap Efisiensi Investasi}

Sesuai dengan hasil pengujian hipotesis kedua dengan menggunakan variabel debt maturity yang diukur dengan menggunakan rasio utang jangka pendek dibagi total hutang, diperoleh nilai prob dari pengujian t-statistik sebesar 0.7704. Proses pengolahan data 
dilakukan dengan menggunakan tingkat kesalahan sebesar 0,05. Hasil yang diperoleh tersebut menunjukan bahwa nilai prob sebesar 0.7704 $\geq$ alpha 0,05 maka keputusannya adalah Ho diterima dan Ha ditolak sehingga dapat disimpulkan bahwa debt maturity yang diukur dengan menggunakan rasio utang jangka pendek dibagi total hutangtidak berpengaruh signifikan terhadap Efisiensi Investasi pada perusahaan manufaktur sektor konsumsi di Bursa Efek Indonesia.

\section{PEMBAHASAN}

\section{Pengaruh Kualitas Laporan Keuangan Terhadap Efisiensi Investasi Pada Perusahaan Manufaktur Sektor Konsumsi di Bursa Efek Indonesia}

Berdasarkan hasil pengujian hipotesis pertama ditemukan bahwa kualitas laporan keuangan yang diukur dengan menggunakan modal kerja akrual berpengaruh positif dan signifikan terhadap efisiensi investasi pada perusahaan manufaktur sektor konsumsi di Bursa Efek Indonesia periode 2015-2017. Semakin tinggi kualitas laporan keuangan akan meningkatkan efisiensi investasi. Hal ini dikarenakan kualitas laporan keuangan secara langsung mempengaruhi para manajer menjadi lebih akuntabel, sehingga dapat mengurangi asimetri informasi dan menurunkan tingkat moral hazard dalam menentukan keputusan investasi.

Hasil yang sejalan dengan hasil pennelitian yang dilakukan Rahmawati \& Harto, (2014),Amrullah, (2013),Sakti, (2015) dan Christine \& Yanti, (2017) yang juga menemukan bahwa kualitas laporan keuangan bepengaruh positif dan signifikan terhadap efisiensi investasi. Hasil ini menunjukan bahwa masih ada sejumlah variabel lain yang lebih mempengaruhi efisiensi investasi seeperti asimetri informasi dan beberapa variabel lainnya, di mana kualitas laporan keuangan yang tinggi dapat membantu perusahaan melakukan investasi secara tepat dan efisien.

Berdasarkan hasil dapat diinterpretasikan bahwa data yang dimaksud adalah bagaimana data asli nilai kualitas laporan keuangan pada perusahaan manufaktur sektor konsumsi yang terdaftar pada Bursa Efek Indonesia. Secara keseluruhan nilai kualitas laporan keuangan rata rata yang dimiliki pada umumnya perusahaan manufaktur sektor konsumsi di Bursa Efek Indonesia adalah 6.406x, kualitas laporan keuangan yang dimiliki perusahaan manufaktur sektor konsumsi secara keseluruhan dapat diinterpretasikan mampu membantu perusahaan untuk melakukan investasi secara efisien. Kualitas pelaporan keuangan yang lebih tinggi akan membantu manajer membuat keputusan investasi dengan identifikasi proyek yang lebih baik dan dapat menghindari keadaan overinvestment dan underinvestment. Perusahaan yang mempunyai tingkat kualitas laporan keuangan yang rendah maka berkemungkinan akan terjadi kondisi overinvestmen dan underinvestment.

\section{Pengaruh Debt Maturity terhadap Efisiensi Investasi pada Perusahaan Manufktur Sektor Konsumsi di Bursa Efek Indonesia.}

Berdasarkan hasil pengujian hipotesis kedua ditemukan bahwa debt matuity yang diukur dengan menggunakan rasio utang jangka pendek dibagi total hutang tidak berpengaruh signifikan terhadap efisiensi investasi pada perusahaan manufaktur sektor konsumsi di Bursa Efek Indonesia periode 2015-2017. Hasil yang diperoleh sejalan dengan penelitian Rahmawati \& Harto, (2014) yang hasil penelitiannya menunjukan bahwa debt maturity tidak berpengaruh signifikan terhadap efisiensi investasi.

Hasil penelitian ini tidak sejalan dengan penelitian Amrullah, (2013), Sakti, (2015) dan Christine \& Yanti, (2017) menunjukan bahwa debt maturity berpengaruh signifikan terhadap efisiensi investasi.

Berdasarkan hasil dapat di interpretasikan bahwa data yang dimaksud adalah bagaimana data asli nilai debt maturity pada perusahaan manufaktur sektor konsumsi yang terdaftar pada Bursa Efek Indonesia. Secara keseluruhan nilai debt maturity rata-rata yang Vol. 8, No. 2, Desember 2019, pp. 342-353 
dimiliki pada umumnya perusahaan manufaktur sektor konsumsi di Bursa Efek Indonesia adalah 9.387x. . Penggunaan utang jangka pendek tidak dapat meningkatkan efisiensi investasi karena tingkat suku bunga di Indonesia lebih tinggi jika dibandingkan dengan tingkat suku bunga di luar negeri. Kondisi ini akan mengakibatkan aliran uang kas pada perusahaan uang kas yang seharusnya bisa digunakan untuk berinvestasi pada akhirnya harus dikeluarkan untuk membayar utang beserta bunganya yang cukup tinggi. Sehingga investasi yang menguntungkan perusahaan tidak dapat dilaksanakan secara maksimal dan efisiensi investasi tidak dapat tercapai.

\section{PENUTUP}

\section{Kesimpulan}

Berdasarkan kepada analisis dan pembahasan hasil pengujian hipotesis yang telah dijelaskan maka dapat diajukan beberapa kesimpulan penting yang merupakan jawaban dari permasalahan yang dibahas di dalam penelitian ini yaitu : 1) Kualitas laporan keuangan diukur menggunakan modal kerja akrual berpengaruh positif dan signifikan terhadap efisiensi investasi pada perusahaan manufaktur sektor konsumsi di Bursa Efek Indonesia. Hasil yang diperoleh disebabkan semakin tinggi kualitas laporan keuangan akan meningkatkan efisiensi investasi, hal ini dikarenakan kualitas laporan keuangan secara langsung mempengaruhi para manajer menjadi lebih akuntabel, sehingga dapat mengurangi asimetri informasi dan menurunkan tingkat moral hazard dalam menentukan keputusan investasi. 2) Debt Maturity diukur menggunakan skala rasio utang jangka pendek dibagi total hutang tidak berpengaruh signifikan terhadap efisiensi investasi pada perusahaan manufaktur sektor konsumsi di Bursa Efek Indonesia karena tingkat suku bunga di Indonesia lebih tinggi jika dibandingkan dengan tingkat suku bunga di luar negeri. Kondisi ini akan mengakibatkan aliran uang kas pada perusahaan uang kas yang seharusnya bisa digunakan untuk berinvestasi pada akhirnya harus dikeluarkan untuk membayar utang beserta bunganya yang cukup tinggi. Sehingga investasi yang menguntungkan perusahaan tidak dapat dilaksanakan secara maksimal dan efisiensi investasi tidak dapat tercapai.

\section{Keterbatasan Penelitian}

Peneliti menyadari bahwa hasil penelitian yang diperoleh di dalam penelitian ini masih memiliki sejumlah kelemahan yang disebabkan oleh adanya keterbatasan yang peneliti miliki yaitu: 1) Jumlah data observasi yang digunakan hanya tiga tahun, untuk penelitian periode observasi dalam tempo waktu tiga tahun digolongkan pendek sehingga mengakibatkan hasil yang diperoleh juga bermanfaat untuk waktu yang relatif pendek. 2) Komposisi data yang digunakan didalam penelitian juga tidak begitu beragam, di mana masih terdapat sejumlah data yang menggunakan rumus log sehingga berakibat pada hasil penelitian yang diperoleh. 3) Masih terdapatnya sejumlah variabel yang juga mempengaruhi efisiensi investasi yang tidak digunakan di dalam penelitian ini seperti asimetri informasi, mekanisme governance dan berbagai variabel lainnya.

\section{DAFTAR PUSTAKA}

Abdullah, M. (2015). Metodologi Penelitian Kuantitatif.

Amrullah, Z. (2013). Pengaruh Kualitas Laporan Keuangan dan Debt Maturity terhadap Efisiensi Investasi Perusahaan di Indonesia.

Biddle, G. C., Hilary, G., \& Verdi, R. S. (2009). How does financial reporting quality relate to investment efficiency? Journal of Accounting and Economics, 48(2-3), 112-131. https://doi.org/10.1016/j.jacceco.2009.09.001 
Chen, F., Hope, O. K., Li, Q., \& Wang, X. (2011). Financial reporting quality and investment efficiency of private firms in emerging markets. Accounting Review, 86(4), 1255-1288. https://doi.org/10.2308/accr-10040

Christine, D., \& Yanti, N. D. (2017). Forum Keuangan Dan Bisnis Indonesia( FKBI ) Pengaruh Kualitas Laporan Keuangan dan Debt Maturity Terhadap Efisiensi Investasi, (204), 19-30.

Cutillas Gomariz, M. F., \& Sánchez Ballesta, J. P. (2014). Financial reporting quality, debt maturity and investment efficiency. Journal of Banking and Finance, 40(1), 494-506. https://doi.org/10.1016/j.jbankfin.2013.07.013

Fajri, S. N. (2013). Pengaruh ukuran perusahaan, struktur kepemilikan dan konsentrasi pasar terhadap kualitas laporan keuangan. Skripsi Universitas Negeri Medan.

Gulo, W. (2002). Metodologi Penelitian.

Hodgson, T. M., Breban, S. J., Ford, C. L., Streat, M. P., \& Urwin, R. C. (2015). The Concept of Investment Ef $\square$ ciency and its Application to Investment, (June 2011), 451-545. https://doi.org/10.1017/S1357321700001884

Jensen, \& Meckling. (1976). Theory of the firm: managerial behavioragency and ownership structure. Journal of Financial Economics, 3, 305-360. https://doi.org/10.1016/0304405X(76)90026-X

Kharismawati, M. E., \& Santosa, U. A. (2014). Efisiensi Investasi Indonesia Semakin Memburuk.

Kuntjojo. (2009). Metodologi Penelitian. Metodologi Penelitian, 51.

Listiadi, A. (2008). Pengaruh Kinerja Keuangan Terhadap Nilai Perusahaan Sebagai Manifestasi Pembelajaran Investasi, 3(1), 197-213.

Mansuri. (2016). Modul Praktikum Eviews Analisis Regresi Linier Berganda Menggunakan Eviews.

Marjudin. (2019). Rasio ICOR Tinggi, Investasi di Indonesia Kurang Efisien.

Mutmainnah, N., \& Wardhani, R. (2013). Analisis Dampak Kualitas Komite Audit Terhadap Kualitas Laporan Keuangan Perusahaan dengan Kualitas Audit sebagai Variabel Moderasi. Jurnal Akuntansi Dan Keuangan Indonesia, 10(2), 147-170. https://doi.org/10.21002/jaki.2013.08

Pradono, F. C., \& Basukianto. (2015). Kualitas Laporan Keuangan Pemerintah Daerah: Faktor yang Mempengaruhi dan Implikasi Kebijakan (Studi Pada SKPD Pemerintah Provinsi Jawa Tengah). Jurnal Bisnis Dan Ekonomi, 22(2), 188-200. https://doi.org/10.1890/11-0650.1

PUTRADIARTA, A. A. (2017). ANALISIS FAKTOR-FAKTOR YANG.

Radjab, E., \& Jam'an, A. (2017). Metodologi Penelitian Bisnis.

Raharjo, T. B. (2017). Pengaruh Karakteristik Perusahaan Terhadap Kualitas Pelaporan Keuangan dan Dampaknya Terhadap Efisiensi Investasi, 10(September), 391-404. https://doi.org/10.15408/akt.v10i2.4681

Rahmawati, A. D., \& Harto, P. (2014). Maturitas Utang Terhadap Efisiensi Investasi, 3, 1-12.

Sakti, A. M. (2015). Pelaporan Kualitas Pelaporan Keuangan Dan Jatuh Tempo Utang terhadap Efisiensi Investasi, 4(2006), 1-10.

Sari, L. I. N. dan I. G. N. A. S. (2014). Pengaruh Kualitas Laporan Keuangan Pada Efisiensi Investasi Perusahaan Pertambangan. E-Joural Akuntansi Universitas Udayana, 3.

Setyawati, L. J. (2015). Kualitas Informasi Pelaporan Keuangan : Faktor- Faktor Penentu Dan Pengaruhnya Terhadap Efisiensi Investasi, (2), 186-196.

Sulistyowati, N. W. (2015). Pengaruh Motivasi Ekstrinsik Dan Prestasi Belajar Akuntansi Terhadap Minat Investasi Mahasiswa Fe Program Studi Akuntansi Unesa, 76-90. 
Syarifudin, A. (2014). Pengaruh Kompetensi SDM dan Peran Audit Intern terhadap Kualitas Laporan Keuangan Pemerintah Daerah dengan Variabel Intervening Sistem Pengendalian Internal Pemerintah (studi empiris pada Pemkab Kebumen). Fokus Bisnis, 14(25), 26-44. https://doi.org/10.1080/10587250210796

Ulum Tri Handayani. (2016). Kualitas Pelaporan Keuangan, Mekanisme Governance. Dan Efisiensi Investasi, 270-287.

UMIYATI, I. (2017). Financial Reporting Quality,Information Asymmetry And Investment Efficiency, 17(1), 39-53.

Verdi, R. S. (2006). Financial Reporting Quality and Investment Efficiency.

Vosoughi, M., Derakhshan, H., \& Alipour, M. (2016). Investigating the relationship between financial distress and investment efficiency of companies listed on the Tehran Stock Exchange. Accounting, 2, 167-176. https://doi.org/10.5267/j.ac.2016.3.003

Winarno, wing wahyu. (2009). Operasional Eviews. Salemba Empat, Jakarta.

Winarno, wing wahyu. (2015). Analisis Ekonometrika dan Statistika dengan EViews (4th ed.). 